\title{
Keman Eğitiminde Türk Halk Müziği Eserlerinin Kullanılma Durumuna Yönelik Öğretim Elemanı Görüşlerinin Değerlendirilmesi
}

\author{
An Evaluation on the Instructor Views of the Use of Turkish Folk Musical \\ Pieces in Violin Education
}

\section{Ozan Gülüm}

Arş. Gör. Dr., Atatürk Üniversitesi K. K. Eğitim Fakültesi Güzel Sanatlar Eğitimi Bölümü Müzik Eğitimi Anabilim Dalı, ozan.gulum@atauni.edu.tr

\section{Aytekin Albuz}

Prof. Dr. Gazi Üniversitesi Gazi Eğitim Fakültesi Güzel Sanatlar Eğitimi Bölümü Müzik Eğitimi Anabilim Dalı, aytekina@gazi.edu.tr

\section{$\ddot{O} \mathbf{z}$}

$\mathrm{Bu}$ araştırmada; müzik eğitimi anabilim dallarında görev yapan 37 keman eğitimcisinin görüşleri çerçevesinde, keman eğitiminde Türk halk müziği eserlerinin kullanılma durumları incelenmiştir. Araştırma genel tarama modelinde betimsel bir çalışmadır. Araştırmada elde edilen verilerin analizinde frekans yüzde analizi kullanılmıştır. Araştırma sonucunda, keman eğitiminde Türk halk müziği eserlerine yeterince yer verilmediği, Türk halk müziği eserlerin keman uyarlamalarında hem özgün yapıların korunması hem de kemanın evrensel icra biçimine uygun yaklaşımların gerektiği ve keman eğitiminde var olan Türk halk müziği eserlerini çalmayı kolaylaştırıcı alıştırmaların az olduğu görüşleri ortaya çıkmıştır.

Anahtar kelimeler: Müzik Eğitimi, Keman Eğitimi, Türk Halk Müziği

\begin{abstract}
In this study, the use of Turkish folk musical pieces in violin education was examined within the frame of the views of 37 violin educators who are working in the departments of music education. The research is a descriptive study in the general survey model. Frequency percentage analysis was used in the analysis of the data obtained in the research. According to the research results, the arguments are revealed that Turkish folk musical pieces are not sufficiently given in the violin education and it is necessary to protect both the original structures and the approaches appropriate for the universal playing form of the violin in the violin adaptations of Turkish folk musical pieces and the exercises which are existing in the violin education and which are facilitating to play Turkish folk musical pieces are limited.
\end{abstract}

Keywords: Music Education, Violin Education, Turkish Folk Music. 


\section{Giriş}

Keman, perdesiz yapısı, etkileyici sesi ve geniş teknik olanakları sayesinde farklı müzik türlerine adapte olabilme özelliği göstermekte, bu nedenle birçok müzik kültüründe kendisine yer bulmaktadır. $\mathrm{Bu}$ durumun doğal bir sonucu olarak keman, Türk müziği icraları için de sıklıkla kullanılan bir çalg1 konumuna gelmiştir.

Kemanın ülkemizde kullanıldığına dair emareler 18.yy ortalarını işaret etse de (Fonton, 1987, s. 89) araştırmacılar kemanın akademik anlamda batılı eğitim-öğretim faaliyetlerinin yürütüldüğ̈̈ ilk kurum olarak 1826 yılında temelleri atılan Muzika-i Hümayun'u işaret etmektedirler (Dalkıran, 2013, s. 174; Gazimihal, 1955, s. 41; Say, 2010, s. 509; Selanik, 1996, s. 293).

Muzika-i Hümayun'dan günümüze geçen yaklaşık 192 (1826-2018) yıllık dönemde kurumsallaşma süreci giderek hızlanan müzik eğitimi ve dolayısıyla keman eğitimi, günümüzde de gelişimini sürdürmektedir.

Keman eğitiminin yaygın bir biçimde yer aldığı günümüz kurumları; Konservatuarlar, Güzel Sanatlar Fakülteleri Müzik Bölümleri, Eğitim Fakülteleri Müzik Öğretmenliği Anabilim Dalları, Güzel Sanatlar Liseleri, bazı kurum ve kuruluşların açtığı kurslar ve özel dershaneler olarak belirtilebilir (Akpınar, 2014, s. 93).

Tüm dünyada olduğu gibi ülkemizde de keman eğitimi süreçleri ağırlıklı olarak evrenselleşmiş keman eğitimi yaklaşımları ve Batı müziği repertuvarında yer alan eser ve etütler ile yürütülmektedir. “Avrupa'da birçok ülkenin geleneksel çalgısı ve Batı(klasik) müziğinin vazgeçilmez bir enstrümanı olması sebebiyle Avrupa kaynaklı keman literatürünün tüm dünyada yaygın olması doğal bir durum olarak kabul edilebilir" (Kurtaslan, 2010, s. 16). Fakat bu durum Türk müziğinin keman eğitimi süreçlerine dâhil edilmesini geri planda tutmamış, aksine uzun yıllardır eğitimcilerimiz ve bestecilerimiz tarafından sunulan eserlerin ve etütlerin yardımıyla keman eğitimi süreçlerine dâhil edilmiştir.

Müzik eğitiminin önemli bir öğesi olan çalg1 eğitiminde, Türk halk müziğinden yararlanılması ve böylece hem çalgı eğitiminin daha verimli ve etkin hale getirilmesi, hem de Türk halk müziğinin çağdaş tekniklerle işlenip dünyaya tanıtılması düşüncesi Cumhuriyet döneminden günümüze kadar üzerinde önemle durulan bir konu olmuştur (Akpınar, 2002, s. 50).

Kemanın birçok müzik eğitimi kurumunda temsili ile ülkemizde yaygınlaşması, beraberinde Türk müziğinin keman eğitimine dâhil edilişi ile ilgili çalışmaları hızlandırmıştır. Bir diğer deyişle artık Türk toplumunca da kabul görmüş kemanın, Türk müziğine ait zenginliklerle teknik olanakları ölçüsünde işlenmesi ve eğitim süreçlerine dâhil edilmesi kaçınılmaz hale gelmiştir. Bu yaklaşım giderek artan biçimde ve önemde uzun yıllardır ele alınmakta, hem Türk müziği kaynaklı özgün veya uyarlama eser, hem etüt ve alıştırmalarda, hem de bilimsel araştırmalarda kendisini göstermektedir. Kurtaslan (2010) bu konudaki bir görüşünü "Türkiye'de Avrupa kaynaklı keman literatürünün yaygın olarak kullanılmasının yanı sıra 1970'li yıllardan itibaren Türk keman ve müzik eğitimcilerinin keman öğretimine yönelik materyal geliştirme çabalarının Türk keman okulunun oluşum ve gelişim sürecine olan katkıları önemlidir" şeklinde belirtmiştir (s. 35). Türk müziğinin keman eğitiminde kullanılma durumunun günümüzde hala araştırmalara konu olmaya devam etmekte olduğuna dair görüşünü Feyzi (2013) "Geleneksel müziğimize ait öğelerin müzik eğitimi sürecine yerleştirilmesinin ve bu öğelerin eğitim-öğretim kaynaklarında yer almasının ülkemizde uzun bir süreç geçirdiği söylenebilir. Bu sürecin günümüzde de gelişerek devam ettiği görülmektedir" biçiminde paylaşmaktadır (s. 2). Günümüzde gelinen noktada ise müzik eğitimcisi yetiştiren kurumlardaki öğrencilerin, batı müziği kökenli etüt ve eserlerin yanı sıra, Türk halk müziğine dayalı etüt ve eserleri de seslendirmesi gereği artık tartışılmamaktadır" (Akpınar, 2002, s. 50). 
Görüldüğü üzere Türk halk müziğinin keman eğitiminde kullanılma durumu hangi boyutta olursa olsun bir gerekliliktir. Bu gerekliliğe uygun olarak da yapılmış bilimsel çalışmalar ve eser yaratıları mevcuttur. Fakat uzun yıllardır yapılan ve hala yapılmakta olan bilimsel çalışmalarda da görüleceği üzere bu konuda arzu edilen düzeye ulaşılmış değildir.

Keman, bütün tarihi süreci boyunca birçok müzik türü içinde yer bulmuş, günümüzde ise, dünyada ve ülkemizde müzik eğitimi veren kurumlarda eğitimi sürdürülen önemli bir müzik enstrümanıdır. Klasik Batı Müziği tarihi boyunca, metodolojisi ve edebiyatı, yazılan eserlerin sayısı itibariyle en zengin enstrüman haline gelmiştir. Osmanlı'nın Batılılaşma hareketleri döneminde ülkemize giren Batı Müziği ve Batı Kemani, Cumhuriyet döneminde açılan bütün müzik eğitimi kurumlarında yer bulmuş ancak metodolojik ve eser dağarı açısından Batıdan alındığı sınırlar içinde kalmış, geleneksel müziğimizden yararlanma konusunda ise yazılmış çok kıymetli fakat az sayıdaki eserle, hem Türk Müziği Keman Okulunu yaratamamış hem de evrensel müziğe kendi ezgisel dünyasını duyuramamıştır (Efe, 2007, s. 2).

"Geleneksel müziklerimizin kendine özgü zengin makamları keman eğitimi için değerli bir malzemedir. $\mathrm{Bu}$ malzemeden keman eğitiminde yeterince faydalanabilmek için makamsal etüt ve alıştırmalara ihtiyaç vardır. Mevcut makamsal keman etüt ve alıştırmaları nitelik ve nicelik bakımından yeterli değildir” (Parasız, 2009, s. 10). Dolayısıyla günümüz keman eğitiminde, Türk halk müziği kaynaklı eserlerin ve alıştırmaların kullanılma durumları hem nicelik bağlamında hem de kullanılma biçimleri açısından merak konusudur. Günümüzde Türk halk müziğinin keman eğitiminde kullanılmasının güncel bir değerlendirmesini ortaya koymak amacıyla, Türk halk müziği kaynaklı eserlerin ve alıştırmaların keman eğitiminde kullanılma durumların belirlenmesi, çalışmada problem durumu olarak ele alınmıştır.

\section{Yöntem}

Araştırma betimsel nitelikli olup araştırmada genel tarama yöntemi kullanılmıştır. "Genel tarama modelleri, çok sayıda elemandan oluşan bir evrende, evren hakkında genel bir yargıya varmak amacı ile evrenin tümü ya da ondan alınacak bir grup, örneklem üzerinde yapılan tarama düzenlemeleridir" (Karasar, 2016, s. 111).

Eğitim fakültelerinin müzik eğitimi anabilim dallarında keman eğitimi alanında görev yapan öğretim elemanları, üniversitelerin internet siteleri akademik kadro sayfaları üzerinden belirlenmiş ve neticesinde toplam 65 kişi tespit edilmiştir. Araştırmanın çalışma grubunu ise Türkiye'deki üniversitelerin müzik eğitimi anabilim dallarında görev yapan keman eğitimcilerinden görüşme formu maddelerine yanıt vererek katılım gösteren 37'si oluşturmaktadır.

Müzik eğitimi anabilim dalları keman eğitimi süreçlerinde Türk halk müziği eserlerinin kullanılma durumlarını belirlemeye dönük hazırlanan görüşme formu, yarı yapılandırılmış olarak 5'li likert tipinde 11 madde ile oluşturulmuştur. Başlangıç, orta ve ileri düzeyde Türk halk müziği eser repertuvarı ve Türk halk müziği eserlerini kemanda çalmayı kolaylaştırıcı alıştırmaların nicel anlamda yeterli olup olmadığının ölçülmesi amacıyla yöneltilen dört madde hariç diğer tüm maddelerde açık uçlu bölüm bırakılarak katılımcılardan eklemek istedikleri görüşleri istenmiştir. Görüşme formunun geçerliği uzman görüşleri ile güvenirliği ise Cronbach's Alpha güvenirlik testi ile sağlanmıştır. İzlenen geçerlik ve güvenirlik adımlarının ardından hazırlanan görüşme formu internet ortamına aktarılmış ve ilgili keman eğitimcilerinin görev yaptıkları üniversitelerin sitelerinde bulunan e-posta adreslerine postalanmıştır. 
Tablo 1

Görüşme formuna ilişskin Cronbach's Alpha güvenirlik testi sonuçları

\begin{tabular}{|c|c|c|}
\hline Sorular & $\mathbf{N}$ & Cronbach's Alpha \\
\hline Keman eğitiminde Türk halk müziği eserlerine yer verilmelidir. & \multirow{11}{*}{37} & ,970 \\
\hline $\begin{array}{l}\text { Türk halk müziği eserleri kemana uyarlanırken yörenin ve bölgenin müzikal üslubu } \\
\text { yansıtılmaya çalışılmalıdır. }\end{array}$ & & 965 \\
\hline $\begin{array}{l}\text { Türk halk müziği eserlerindeki üslup ve özgün yapılar kemanın evrensel icra biçimine } \\
\text { uygun olarak düzenlenebilir. }\end{array}$ & & ,964 \\
\hline $\begin{array}{l}\text { Türk kalk müziği eserleri kemana uyarlanırken, öğrencinin teknik ve müzikal } \\
\text { becerilerini geliştirmeye dönük materyallerin kullanımına özen gösterilmelidir. }\end{array}$ & & ,964 \\
\hline $\begin{array}{l}\text { Keman eğitiminde başlangıç düzeyinde kullanılan ve kemana uyarlanmış Türk halk } \\
\text { müziğine dayalı repertuvar nicelik bakımından yeterli düzeydedir. }\end{array}$ & & ,966 \\
\hline $\begin{array}{l}\text { Keman eğitiminde orta düzeyde kullanılan ve kemana uyarlanmış Türk halk müziğine } \\
\text { dayalı repertuvar nicelik bakımından yeterli düzeydedir. }\end{array}$ & & 965 \\
\hline $\begin{array}{l}\text { Keman eğitiminde ileri düzeyde kullanılan ve kemana uyarlanmış Türk halk müziğine } \\
\text { dayalı repertuvar nicelik bakımından yeterli düzeydedir }\end{array}$ & & 966 \\
\hline $\begin{array}{l}\text { Türk halk müziği eserlerinin kemanda icrasına yönelik egzersiz, alıştırma ve etüt vb. } \\
\text { nicelik bakımından yeterli düzeydedir. }\end{array}$ & & 971 \\
\hline $\begin{array}{l}\text { Türk halk müziği eserlerinin kemanda icrasını kolaylaştırıcı alıştırmalar keman } \\
\text { eğitiminde daha çok yer almalıdır. }\end{array}$ & & 965 \\
\hline Keman eğitiminde Türk halk müziği eserleri mikrotonal ses sisteminde icra edilebilir. & & ,967 \\
\hline Türk halk müziği eserlerinin uyarlamaları, keman eğitiminde daha çok yer almalıdır. & & ,964 \\
\hline Toplam & 37 & ,969 \\
\hline
\end{tabular}

Tablo 1'de anket sorularının teker teker güvenilirlik durumları ve anket toplam soru güvenilirlik durumları görülmektedir. Anketin hem ayrı ayrı soru bazında, hem de toplam soru bazında güvenilirliği sağladığ 1 (Cronbach's Alpha (a) = 0,969 > 0,60) yapılan istatistiksel analiz sonucunda belirlenmiştir.

Verilerin analizinde SPSS 17 istatistik paket programı kullanılmıştır. 11 madde üzerinde 5'li likert tipine yönelik cevapları nicel verilere dönüştürmek açısından frekans-yüzde analizi kullanılmıştır. Keman eğitimcilerinin vermiş olduğu açık uçlu cevaplar ise araştırmacılar tarafindan kontrol edilerek, belirli bir sistematik içerisinde tasnif edilmiş ve eğitimcilerin vermiş oldukları cevaplar doğrultusunda ortak görüşlerini yansıtacak şekilde genelleştirilerek sunulmuştur.

\section{Bulgular ve Yorum}

$\mathrm{Bu}$ bölümde, Türk halk müziği eserlerinin keman eğitiminde kullanılma durumuna ilişkin keman eğitimcilerinin görüşleri tablolar halinde sunulmuş ve yorumlar yapılmıştır.

Tablo 2

Birinci maddeye verilen cevaplara ilişkin frekans-yüzde tablosu.

\begin{tabular}{|c|c|c|c|}
\hline Ölçüt & Yanıtlar & Frekans & Yüzde \\
\hline \multirow{6}{*}{ Keman eğitiminde Türk halk müziği eserlerine yer verilmelidir. } & Kesinlikle Katılmıyorum & - & - \\
\hline & Katılmiyorum & - & - \\
\hline & Kismen Katıliyorum & - & - \\
\hline & Katıliyorum & 8 & 21,6 \\
\hline & Kesinlikle Katılıyorum & 29 & 78,4 \\
\hline & Toplam & 37 & 100 \\
\hline
\end{tabular}

Tablo 2'de görüldüğ̈̈ üzere keman eğitiminde Türk halk müziği eserlerine yer verilmelidir maddesine verilen yanıtlardan, 29'u $(\% 78,4)$ kesinlikle katılıyorum, 8'i $(\% 21,6)$ katıliyorum biçiminde olup; kesinlikle katılmıyorum, katılmıyorum ve kısmen katılıyorum seçeneklerini tercih eden öğretim elemanı ise olmamıştır. Bu durum; öğretim elemanlarında keman eğitiminde Türk halk müziği eserlerinin kullanımının büyük ölçüde yararlı olacağı kanaati oluştuğuna dair bir gösterge olarak algılanabilir. 
Tablo 3

İkinci maddeye verilen cevaplara ilişkin frekans yüzde tablosu

\begin{tabular}{|c|c|c|c|}
\hline Ölçüt & Yanıtlar & Frekans & Yüzde \\
\hline \multirow{6}{*}{$\begin{array}{l}\text { Türk halk müziği eserleri kemana uyarlanırken yörenin ve bölgenin } \\
\text { müzikal üslubu yansıtılmaya çalışılmalıdır. }\end{array}$} & Kesinlikle Katılmıyorum & - & - \\
\hline & Katılmiyorum & - & - \\
\hline & Kismen Kat1liyorum & 3 & 8,1 \\
\hline & Katıliyorum & 11 & 29,7 \\
\hline & Kesinlikle Katılıyorum & 23 & 62,2 \\
\hline & Toplam & 37 & 100 \\
\hline
\end{tabular}

Tablo 3'te görüldüğü üzere Türk halk müziği eserleri kemana uyarlanırken yörenin ve bölgenin müzikal üslubu yansitılmaya çalışılmalıdır maddesine verilen yanıtlardan 3'ü $(\% 8,1)$ kısmen kat1lıyorum, 11'i $(\% 29,7)$ katılıyorum, 23'ü $(\% 62,2)$ kesinlikle katılıyorum biçimindedir. Katılmıyorum ve kesinlikle katılmıyorum seçeneğini tercih eden öğretim elemanı olmamıştır. Öğretim elemanlarının \%91,9 düzeyinde olumlu görüşlerinden hareketle Türk halk müziği eserleri kemana uyarlanırken mümkün olduğu ölçüde yörenin ve bölgenin müzikal üslubunun yansıtılması gerektiği kanaatinde oldukları söylenebilir.

Tablo 4

Ü̧̧йcü maddeye verilen cevaplara ilişkin frekans-yüzde tablosu.

\begin{tabular}{|c|c|c|c|}
\hline Ölçüt & Yanitlar & Frekans & Yüzde \\
\hline \multirow{6}{*}{$\begin{array}{l}\text { Türk halk müziği eserlerindeki üslup ve özgün yapılar kemanın } \\
\text { evrensel icra biçimine uygun olarak düzenlenebilir. }\end{array}$} & Kesinlikle Katılmıyorum & 1 & 2,7 \\
\hline & Katılmiyorum & - & - \\
\hline & Kismen Katıliyorum & 7 & 18,9 \\
\hline & Katıliyorum & 8 & 21,6 \\
\hline & Kesinlikle Katılıyorum & 21 & 56,8 \\
\hline & Toplam & 37 & 100 \\
\hline
\end{tabular}

Tablo 4'te; Türk halk müziği eserlerindeki üslup ve özgün yapılar kemanın evrensel icra biçimine uygun olarak düzenlenebilir maddesine verilen yanıtlardan 1'inin $(\% 2,7)$ kesinlikle katılmıorum, 7'sinin $(\% 18,9)$ kısmen katılıyorum, 8 'inin $(\% 21,6)$ katılıyorum, 21 'inin $(\% 56,8)$ kesinlikle kat1lıyorum olduğu görülmektedir. Öğretim elemanlarının \%78,4 düzeyinde olumlu görüşleri neticesinde, gerekli hallerde Türk halk müziği eserlerindeki üslup ve özgün yapılarının kemanın evrensel biçimine uygun olarak düzenlenebileceğini düşündükleri anlaşılmaktadır.

Tablo 5

Dördüncü maddeye verilen cevaplara ilişkin frekans yüzde tablosu

\begin{tabular}{|c|c|c|c|}
\hline Ölçüt & Yanitlar & Frekans & Yüzde \\
\hline \multirow{6}{*}{$\begin{array}{l}\text { Türk halk müziği eserleri kemana uyarlanırken, öğrencinin teknik ve } \\
\text { müzikal becerilerini geliştirmeye dönük materyallerin kullanımına özen } \\
\text { gösterilmelidir. }\end{array}$} & Kesinlikle Katılmiyorum & - & - \\
\hline & Katılmıyorum & 1 & 2,7 \\
\hline & Kismen Katıliyorum & 3 & 8,1 \\
\hline & Katılıyorum & 10 & 27,0 \\
\hline & Kesinlikle Katıliyorum & 23 & 62,2 \\
\hline & Toplam & 37 & 100 \\
\hline
\end{tabular}

Tablo 5'te görüldüğü üzere Türk halk müziği eserleri kemana uyarlanırken, öğrencinin teknik ve müzikal becerilerini geliştirmeye dönük materyallerin kullanımına özen gösterilmelidir maddesine verilen yanıtlardan 1'i $(\% 2,7)$ katılmıyorum 3'ü $(\% 8,1)$ kısmen katılıyorum, 10'u $(\% 27,0)$ kat1lıyorum, 23'ü $(\% 62,2)$ kesinlikle katılıyorum olmuştur. Öğretim elemanlarının \%27 katılıyorum ve \%62,2 kesinlikle katılıyorum cevapları 1şığında; \%89,2 düzeyinde Türk halk müziği eserleri kemana uyarlanırken öğrencinin teknik ve müzikal becerilerini geliştirmeye dönük materyallerin kullanılması gerektiği yönünde olumlu görüş bildirdikleri anlaşılmaktadır. 
Tablo 6

Beşinci maddeye verilen cevaplara ilişkin frekans yüzde tablosu

\begin{tabular}{|c|c|c|c|}
\hline Ölçüt & Yanitlar & Frekans & Yüzde \\
\hline \multirow{3}{*}{$\begin{array}{l}\text { Keman eğitiminde başlangıç düzeyinde kullanılan ve kemana } \\
\text { uyarlanmış Türk halk müziğine dayalı repertuvar nicelik bakımından } \\
\text { yeterli düzeydedir. }\end{array}$} & Kismen Katıliyorum & 9 & 24,3 \\
\hline & Kesinlikle Katılıyorum & - & - \\
\hline & Toplam & 37 & 100 \\
\hline
\end{tabular}

Tablo 6'da Keman eğitiminde başlangıç düzeyinde kullanılan ve kemana uyarlanmış Türk halk müziğine dayalı repertuvar nicelik bakımından yeterli düzeydedir maddesine verilen yanitlardan 8'inin $(\% 21,6)$ kesinlikle katılmiyorum, 19'unun (\%51,4) katılmıyorum, 9'unun (\%24,3) kısmen kat1lyorum, 1'inin $(\% 2,7)$ katılıyorum olduğu görülmektedir. Kesinlikle katıliyorum seçeneğini tercih eden öğretim elemanı olmamıştır. Öğretim elemanlarının \%73 düzeyinde olumsuz görüş bildirmelerinden hareketle keman eğitiminde başlangıç düzeyinde kullanılan ve kemana uyarlanmış Türk halk müziğine dayalı repertuvarın nicelik açısından yeterli düzeyde olmadığı söylenebilir.

Tablo 7

Altıncı maddeye verilen cevaplara ilişkin frekans yüzde tablosu

\begin{tabular}{|c|c|c|c|}
\hline Ölçüt & Yanitlar & Frekans & Yüzde \\
\hline \multirow{5}{*}{$\begin{array}{l}\text { Keman eğitiminde orta düzeyde kullanılan ve kemana uyarlanmış Türk } \\
\text { halk müziğine dayalı repertuvar nicelik bakımından yeterli düzeydedir. }\end{array}$} & Kesinlikle Katılmıyorum & 9 & 24,3 \\
\hline & Katılmiyorum & 17 & 45,9 \\
\hline & Kismen Katıliyorum & 11 & 29,7 \\
\hline & Kesinlikle Katılıyorum & - & - \\
\hline & Toplam & 37 & 100 \\
\hline
\end{tabular}

Tablo 7'de görüldüğü üzere Keman eğitiminde orta düzeyde kullanılan ve kemana uyarlanmış Türk halk müziğine dayalı repertuvar nicelik bakımından yeterli düzeydedir maddesine verilen yanıtlardan 9'u $(\% 24,3)$ kesinlikle katılmıyorum, 17'si (\%45,9) katılmıorum, 11'i $(\% 29,7)$ kısmen kat1liyorum olmuştur. Katılıyorum ve kesinlikle katılıyorum seçeneğini ise tercih eden öğretim elemanı olmamıştır. Öğretim elemanlarının \%70,2 düzeyinde olumsuz görüş bildirmelerinden yola çıkarak, keman eğitiminde orta düzeyde kullanılan ve kemana uyarlanmış Türk halk müziğine dayalı repertuvarın nicelik açısından yeterli düzeyde olmadığı söylenebilir.

Tablo 8

Yedinci maddeye verilen cevaplara ilişkin frekans yüzde tablosu

\begin{tabular}{|c|c|c|c|}
\hline Ölçüt & Yanitlar & Frekans & Yüzde \\
\hline \multirow{5}{*}{$\begin{array}{l}\text { Keman eğitiminde ileri düzeyde kullanılan ve kemana uyarlanmış Türk } \\
\text { halk müziğine dayalı repertuvar nicelik bakımından yeterli düzeydedir. }\end{array}$} & Kesinlikle Katılmıyorum & 11 & 29,7 \\
\hline & Kismen Katıliyorum & 7 & 18,9 \\
\hline & Katıliyorum & - & - \\
\hline & Kesinlikle Katıliyorum & - & - \\
\hline & Toplam & 37 & 100 \\
\hline
\end{tabular}

Tablo 8'de Keman eğitiminde ileri düzeyde kullanılan ve kemana uyarlanmış Türk halk müziğine dayalı repertuvar nicelik bakımından yeterli düzeydedir maddesine verilen yanıtlardan 11'inin $(\% 29,7)$ kesinlikle katılmıyorum, 19'unun (\%51,4) katılmıyorum, 7'sinin $(\% 18,9)$ kısmen katılıyorum olduğu görülmektedir. Katılıyorum ve kesinlikle katılıyorum seçeneğini tercih eden öğretim elemanı olmamıştır. Öğretim elemanlarının \%81,1 düzeyinde olumsuz görüş bildirmelerinden hareketle keman eğitiminde ileri düzeyde kullanılan ve kemana uyarlanmış Türk halk müziğine dayalı repertuvarın nicelik açısından yeterli düzeyde olmadığı söylenebilir. 
Tablo 9

Sekizinci maddeye verilen cevaplara ilișkin frekans yüzde tablosu

\begin{tabular}{|c|c|c|c|}
\hline Ölçüt & Yanitlar & Frekans & Yüzde \\
\hline \multirow{6}{*}{$\begin{array}{l}\text { Türk halk müziği eserlerinin kemanda icrasına yönelik egzersiz, } \\
\text { alıştırma, etüt vb. nicelik bakımından yeterli düzeydedir. }\end{array}$} & Kesinlikle Katılmıyorum & 17 & 45,9 \\
\hline & Katılmiyorum & 16 & 43,2 \\
\hline & Kismen Kat1liyorum & 4 & 10,8 \\
\hline & Katıliyorum & - & - \\
\hline & Kesinlikle Katılıyorum & - & - \\
\hline & Toplam & 37 & 100 \\
\hline
\end{tabular}

Tablo 9'da görüldüğü üzere Türk halk müziği eserlerinin kemanda icrasına yönelik egzersiz, alıștırma ve etüt $v b$. nicelik bakımından yeterli düzeydedir maddesine verilen yantlardan 17 'si $(\% 45,9)$ kesinlikle katılmıyorum, 16's1 (\%43,2) katılmıyorum, 4'ü $(\% 10,8)$ kısmen katılıyorum olmuştur. Katıliyorum ve kesinlikle katılıyorum seçeneğini tercih eden öğretim elemanı olmamıştır. Öğretim elemanlarının \%89, 1 düzeyinde olumsuz görüş bildirmeleri neticesinde, Türk halk müziği eserlerinin kemanda icrasına yönelik egzersiz, alıştırma, etüt vb. materyallerin nicelik açısından yeterli düzeyde olmadığı söylenebilir.

Tablo 10

Dokuzuncu maddeye verilen cevaplara ilişkin frekans yüzde tablosu

\begin{tabular}{|c|c|c|c|}
\hline Ölçüt & Yanitlar & Frekans & Yüzde \\
\hline \multirow{5}{*}{$\begin{array}{l}\text { Türk halk müziği eserlerinin kemanda icrasını kolaylaştırıcı egzersiz, } \\
\text { alıştırma etüt vb. keman eğitiminde daha çok yer almalıdır. }\end{array}$} & Kesinlikle Katılmıyorum & - & - \\
\hline & Katılmiyorum & 1 & 2,7 \\
\hline & Kismen Kat1liyorum & 2 & 5,4 \\
\hline & Kesinlikle Katılıyorum & 22 & 59,5 \\
\hline & Toplam & 37 & 100 \\
\hline
\end{tabular}

Tablo 10'da Türk Halk Müziği eserlerinin kemanda icrasını kolaylaştırıcı alıştırmalar yapılabilir maddesine verilen yanıtlardan 1'inin (\%2,7) katılmıyorum, 2'sinin $(\% 5,4)$ kismen kat1lıyorum, 12 'sinin $(\% 32,4)$ kat1liyorum, 22'sinin $(\% 59,5)$ kesinlikle katıliyorum biçiminde olduğu görülmektedir. Kesinlikle katılmıyorum seçeneğini tercih eden öğretim elemanı olmamıştır. Öğretim elemanlarının \%91,9 düzeyinde olumlu görüş bildirmelerinden hareketle Türk halk müziği eserlerinin kemanda icrasını kolaylaştırıcı alıştırmaların keman eğitiminde daha çok yer alması gerektiği kanaatinde oldukları söylenebilir.

Tablo 11

Onuncu maddeye verilen cevaplara ilişkin frekans yüzde tablosu

\begin{tabular}{|c|c|c|c|}
\hline Ölçüt & Yanitlar & Frekans & Yüzde \\
\hline \multirow{3}{*}{$\begin{array}{l}\text { Keman eğitiminde Türk halk müziği eserleri mikrotonal ses sisteminde } \\
\text { icra edilebilir. }\end{array}$} & Kismen Kat1liyorum & 6 & 16,2 \\
\hline & Kesinlikle Katılıyorum & 13 & 35,1 \\
\hline & Toplam & 37 & 100 \\
\hline
\end{tabular}

Tablo 11'de görüldüğü üzere Keman eğitiminde Türk halk müziği eserleri mikrotonal ses sisteminde icra edilebilir maddesine verilen yantlardan 3'ü $(\% 8,1)$ kesinlikle kat1lmıyorum, 3'ü $(\% 8,1)$ katılmıyorum, 6's1 (\%16,2) kısmen katılıyorum, 12'si (\%32,4) katılıyorum, 13’ü $(\% 35,1)$ kesinlikle katılıyorum biçimindedir. Öğretim elemanlarının \%67,5 düzeyinde olumlu görüş bildirmelerinden hareketle keman eğitiminde Türk halk müziği eserlerinin mikrotonal ses sistemi ile icra edilebileceğini düşündükleri söylenebilir. 
Tablo 12

On birinci maddeye verilen cevaplara ilişkin frekans yüzde tablosu

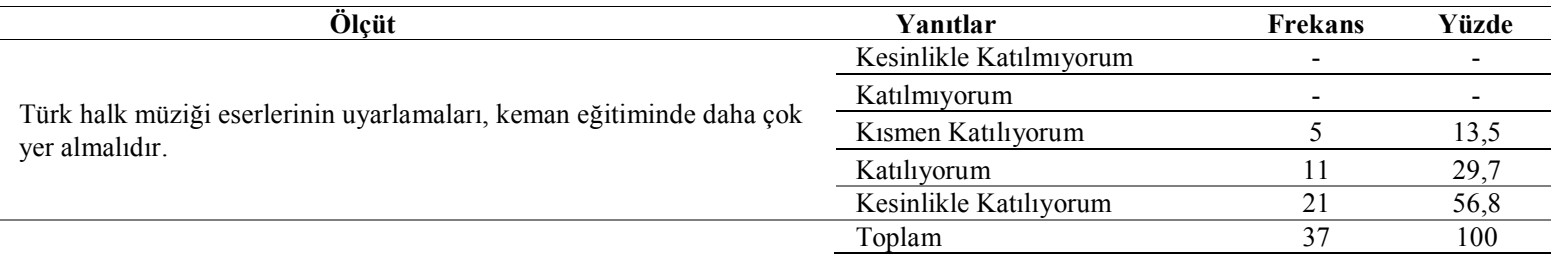

Tablo 12'de görüldüğü üzere Türk halk müziği eserlerinin uyarlamalarl, keman eğitiminde daha çok yer almalıdır maddesine verilen yantlardan 5'i $(\% 13,5)$ kısmen kat1liyorum, 11'i $(\% 29,7)$ kat1lyorum, 21 'i $(\% 56,8)$ kesinlikle katılıyorum biçimindedir. Katılmıyorum ve kesinlikle katılmıorum seçeneğini tercih eden öğretim elemanı olmamıştır. Öğretim elemanlarının \%86,5 düzeyinde olumlu görüş bildirmelerinden hareketle keman eğitiminde Türk halk müziği eserlerinin uyarlamalarına, keman eğitiminde daha çok yer verilmesi gerektiğini düşündükleri söylenebilir.

Görüşme formunda ayrıca öğretim elamanlarının eklemek istediği görüşlerine dair açık uçlu bir bölüm bırakılmıştır. Bu bölümde öğretim elemanlarının keman eğitiminde Türk halk müziği eserlerine yer verilmelidir maddesinde görüşleri genel itibari ile keman eğitiminde keman çalmaya ilişkin davranışların kazandırılması, ulusal repertuvara ait eserlerin yardımıyla kolaylaştırılabilir şeklindedir.

Türk halk müziği eserlerindeki üslup ve özgün yapılar kemanın evrensel icra biçimine uygun olarak düzenlenmelidir maddesinde görüşleri genel itibari ile Türk halk müziğine özgü yapılar ve kemanda evrensel icra biçimleri bir denge içinde ele alınmal ve birbirlerine yapabilecekleri negatif yaklaşımlardan kaçınılmalıdır olarak ifade edilebilir.

Türk halk müziği eserleri kemana uyarlanırken, öğrencinin teknik ve müzikal becerilerini geliştirmeye dönük materyallerin kullanımına özen gösterilmelidir maddesinde görüşleri ele alınacak eserin ve ögrencinin seviyesine bağlı olarak değişkenlik göstermesi gerekir şeklinde özetlenebilir.

Türk halk müziği eserlerinde var olan mikrotonal sesler keman eğitiminde halk ezgileri yoluyla kullanılabilir maddesinde ise görüşleri genel itibari ile mikrotonal seslerin Türk halk müziği eserleri keman uyarlamalarında kullanılması durumunda evrensel niteliklerin dişına çıkılabilir; temel makamlarda düşünülebilse de bileşik makamlarda ne ölçüde uygulanabileceği tartışmalıdır; başlangıçta olmasa da evrensel keman eğitimine dair gerekli müzikal ve teknik birikimlerin sağlanmasının ardından ileri aşamalarda kullanılabilir biçiminde toparlanabilir.

\section{Sonuç ve Tartışma}

Keman eğitimcilerimiz, keman sanatçılarımız ve akademik araştırma yapan bilim insanlarımızca ortaya konulan çalışmalar göz önüne alınarak, yaklaşık yüz yıldır keman eğitiminde Türk müziği ve Türk müziğinde keman olgularının bir bütün olma yoluna doğru seyretmekte olduğu söylenebilir. Keman eğitiminde Türk halk müziğinin kullanımı, hem var olan eserlerin uyarlanması, hem de keman için özgün eserler bestelenmesi şeklinde görülmektedir. Ayrıca gelişmekte olan repertuvarın icrasında kolaylık sağlamaya dönük alıştırma ve etüt çalışmaları olağanca hızıyla sürmektedir. Bir kez daha bu araştırmada güncel bir sonuç olarak ortaya çıkmaktadır ki; keman eğitiminde Türk halk müziği eserlerinin keman uyarlamalarına mutlaka yer verilmelidir. Öğretim elemanlarının yazılı cevaplarının genelinde ortaya çıkan "evrensel keman eğitiminde öncelikle öğrencinin öz kültürüne ait müziklerden hareket edilmesinin kazandırılacak davranışlar üzerinde etkililiği yüksektir" görüşü bu düşünceyi desteklemektedir. Günay ve Uçan'ın (1980) çağdaş Türk keman eğitiminin temel ilkeleri arasında Türk müziğine dayalılık ilkesini belirtmeleri, araştırmada ortaya çıkan bu sonucu destekler niteliktedir (s. 8). 
Araştırmada elde edilen bir diğer sonuç Türk halk müziği eserlerinin uyarlanmasına dair göz önüne alınacak durumlarla ilgilidir. Keman eğitimine uyarlanacak Türk halk müziği eserlerindeki yöre ve bölgeye ilişkin müzikal üslubun evrensel icra biçimine uygun olarak yansıtılması ve bu yapılırken öğrencinin teknik ve müzikal becerilerini geliştirmeye dönük materyallerin kullanımına özen gösterilmesi gerektiği öğretim elemanlarının ortak kanaatidir. Öğretim elemanlarının yazılı görüşleri doğrultusunda böylesi yaklaşımlarda dikkat edilmesi gereken nokta, evrensel tekniklerin kullanımında geleneksel çizgiyi bozacak yaklaşımlardan kaçınılmasıdır. Müezzinoğlu (2012) halk ezgilerinin uyarlanmasında, ele alınan eserdeki ritimsel, makamsal, ezgisel unsurların yanında keman eğitiminde kullanılan bazı teknik ve müzikal unsurların da dikkate alınmasının gerekli olduğu hususunu vurgulayarak bu konuda benzer düşünceleri dile getirmektedir (s. 21). Türk halk müziği eserlerinin kemanın evrensel icra biçimi ile ele alınması konusunda Akyürek (2002) "Türk halk ezgilerinin evrensel keman teknikleriyle bir araya getirilip uyarlanması, düzenlenmesi bilhassa başlangıç aşamasında çalgısıyla bütünleşme çabasında olan öğrenciye büyük aşamalar kazandıracaktır" ifadelerini kullanmıştır (s. 7). Ayrıca Uçan ve Günay (1975) evrensel icra biçimi ile Türk müziğinin kemanda buluşması neticesinde ezgilerin daha parlak ve keskin bir ifadeye kavuşturulabileceğini, Türk müziğinin özelliklerine uygun bir keman tekniği temelinin oluşturulabileceğini ve bu yolla da evrensel keman tekniğine katkı sunulabileceğini belirtmektedirler (s. 8).

Başlangıç, orta ve ileri düzeyde kemana uyarlanmış Türk halk müziği eserlerinin bu gün hala nicel boyutta yeterli düzeyde olmadığı araştırmada ortaya çıkan bir diğer sonuçtur. Bu konudaki ihtiyacı karşılamak amacıyla yapılan tüm çalı̧̧malara rağmen, günümüzde bu eksikliğin giderilemediği görülmektedir. Parasız (2009) "Çalgı eğitimi üzerine yapılan araştırmalar ve yazılan görüşler ekseninde, çalg1 eğitiminin ulusaldan evrensele yapılması görüsü ağırlıklı olmasına rağmen, bu alanda yapılan çalışmaların yetersiz olduğu ve aynı zamanda hazırda olanların bilinemediği veya popüler olmadığı, var olan eserlerin seslendirilmesinde de güçlükler yaşandığ 1 görülmektedir" cümlesiyle bu konuya değinmiştir (s. 5).

Araştırmadaki bir diğer sonuç; Türk halk müziği eserlerinin kemanda icrasına yönelik egzersiz, alıştırma, etüt vb. çalışmaların nicelik bakımından yeterli olmadı̆̆ıdır.

Günümüzde birçok müzik eğitimi kurumunun öğretim programlarında yer alan bireysel çalg1 eğitimi derslerinde seslendirmek üzere türküler, klasik batı müziği teknikleri ve terimleri kullanılarak düzenlenmeli, öğrencilerin bu türküleri yörelerine en uygun bir şekilde seslendirebilmeleri sağlanabilmeli, türkülerin vermek istediği duyguları yansıtabilecek pozisyon ve yay teknikleri vb. kullanılmalıdır. Türküleri ayrıntılı bir biçimde ele alarak seslendirmede rastlanabilecek güçlükleri çözmeye yönelik dizi-gam çalışmaları yapmak ve alıştırmalar hazırlamak, çalgı öğretim süreçlerini de olumlu yönde etkileyecektir (Demirci, 2013, s. 127).

Yakın tarihli çalışmalarda hem alıştırma hem de eser repertuvarındaki ihtiyaç ve bunların nicelik bağlamında yetersizliğe dair yapılan eleştiriler, geçmiş araştırmalarda da karşımıza çıkmaktadır. Şen (1992) Türk halk müziği kaynaklı evrensel keman tekniklerini kullanarak özgün alıştırmalar ortaya koyduğu çalışmasında bu konudaki niceliksel yetersizliğe dikkat çekmektedir (s. 22). Görüldüğü üzere bu araştırmada ortaya konan Türk halk müziği kaynaklı eser, alıştırma, etüt vb. materyallerin önemi fakat nicel anlamda yetersiz olmaları durumu, Türk halk müziğinin keman eğitiminde kullanılmasına dair yapılmış bilimsel çalışmalarda karşımıza çıkmaktadır. Yapılan birçok çalışmaya rağmen, günümüzde hala böylesi bir eksikliğin var olması düşündürücüdür. Bu duruma neden olarak; Nota yayın ve yayımcılığı konusunda Türkiye'de pek az kuruluş olması, Türk halk müziği kaynaklı keman eserlerin birçoğunun notalarına güçlükle ulaşılması, Türk halk müziği kaynaklı alıştırma ve eserlerin çokça seslendirilmemesinden kaynaklı tanınırlık düzeyinin azlığı, Özellikle bilimsel tezlerde ortaya 
konulan eser ve alıştırmaların birçoğunun edisyonunun ve basımının bulunmaması, Keman eğitimcilerinin muhtemel olarak bu sebeplerden ötürü, planlı yürütülen keman eğitimi süreçlerine bunları dâhil edememesi ya da etmemesi gösterilebilir.

Araştırmada elde edilen bir diğer dikkat çekici sonuç ise öğretim elemanlarının keman eğitiminde Türk halk müziği eserlerinin mikrotonal ses sisteminde icra edilebileceğine dair ağırlıklı olarak sundukları olumlu görüştür. Gelişen teknoloji ile iletişim imkânlarının artması müzik kültürleri arasındaki etkileşimin önünü açmıştır. Bu durum beraberinde geleneksel müzikleri, yerel çalgılardaki tınıları daha yaygın müzik türleri ile işlemenin ve daha geniş kitlelere ulaştırmanın kolaylaşmasına neden olmaktadır. Günümüzde dünyaca ünlü bir rap şarkısında zurnanın makamsal icrasını duymak, bir pop türü şarkıda mikrotonal seslerle karşılaşmak artık şaşırtıcı olmaktan uzaktır. Ayrıca klasik batı müziği bağlamında olmasa da bu müzik ekseninde eğitim almış bestecilerin artık tampereman ses sisteminin duvarlarını esnettiği ve çeyrek ton sistemi ile mikrotonal sesler içeren eserler ürettiği bilinmektedir. Mikrotonal seslerin her geçen gün farklı müzik türlerinde kullanımının artması ve bu araştırmada elde edilen sonuçlar nedeniyle, mikrotonal seslerin keman eğitiminde kullanılabilirlik durumu, Türkiye'de keman eğitimi verilen tüm örgün eğitim kurumlarını kapsayacak şekilde incelenmeli ve elde edilen sonuçlar ortaya konulmalıdir.

Son olarak; keman eğitiminde Türk halk müziği eserlerine daha çok yer verilmesi gerektiğinin öğretim elemanlarının ortak görüşü olduğu sonucuna ulaşılmıştır. Bu nedenle hem Türk halk müziği kaynaklı eser üretme çalışmalarının, hem de keman eğitimi için Türk halk müziği eserlerini uyarlama süreçlerini araştıran çalışmaların, özellikle yayın ve yayım konusunda desteklenmesi gerektiği düşünülmektedir.

\section{Kaynakça}

Akpınar, M. (2002). Türk halk müziğinin keman ile seslendirilmesi üzerine bir araştırma. Selçuk Üniversitesi Sosyal Bilimler Enstitüsü Dergisi, 8, 47-55.

Akpınar, M. (2014). Kemanda martele yay tekniğinin öğretilmesinde Türk halk ezgilerinin kullanılmas1. Zeitschrift für die Welt der Türken/Journal of World of Turks, 6 (3), 91-98.

Akyürek, R. (2002). Trabzon'da müzik eğitimcisi yetiştirmeye dönük lise ve yükseköğrenim kurumlarında ege türküleri yoluyla başlangıç düzeyindeki keman tekniklerinin öğrencilere kazandırılması ve bu yaklaşımın keman eğitiminde kullanılabilirliği. (Yüksek lisans tezi). Yök tez veri tabanından erişildi (Tez no: 121935).

Dalkıran, E. (2013). Cumhuriyet'e geçiş ve cumhuriyet dönemi müzik yaklaşımları. Z. Nacakçı \& A. Canbay (Ed.), Müzik Kültürü (s.173-195). Ankara: Pegem Yayınc1lı.

Demirci, B. (2013). Viyolonsel eğitiminde geleneksel Türk müziğine yönelik bir çalışma modeli. Hacettepe Üniversitesi Eğitim Fakültesi Dergisi, 28 (28-1), 117-129.

Efe, M. (2007). Geleneksel Türk sanat müziği kemani bestekârlarının eserlerindeki batı müziğine ait müzikal unsurlar ve keman eğitiminde kullanılabilirliği (Doktora tezi). Yök tez veri tabanından erişildi (Tez no: 206985).

Feyzi, A. (2013). Keman öğretiminde ADDIE yaklaşımı esas alınarak hazırlanan öğretim modelinin uşşak ezgilerin kemanla seslendirilmesine etkileri. (Doktora tezi). Yök tez veri tabanından erişildi (Tez no: 349038).

Fonton, C. (1987). 18.yüzyılda Türk müziği (C. Behar, Çev.). İstanbul: Pan Yayıncılık.

Gazimihal, M. R. (1955). Türk askeri muzıkaları Tarihi. İstanbul: Maarif Yayınları. 
Günay, E., \& Uçan, A. (1980). Çevreden evrene keman eğitimi 1. Ankara: Önder Matbaas1.

Karasar, N. (2016). Bilimsel araştırma yöntemi: kavramlar-ilkeler-teknikler. Ankara: Nobel Yayıncılık.

Kurtaslan, Z. (2010). Müzik öğretmeni yetiştiren kurumlardaki keman eğitiminde çağdaş Türk keman eserlerinin kullanılma durumuna ilişkin öğretim elemanı görüşleri. (Doktora Tezi). Yök tez veri tabanından erişildi (Tez no: 258513).

Müezzinoğlu, A. (2012). Kemana uyarlanmış halk ezgilerinin keman eğitiminde kullanılması. (Doktora tezi). Yök tez veri tabanından erişildi (Tez no: 310959 ).

Parasız, G. (2009). Keman öğretiminde kullanılmakta olan çağdaş Türk müziği eserlerinin seslendirilmesine yönelik olarak oluşturulan hazırlayıcı alıştırmaların işgörüsellik ve etkililik yönünden incelenmesi. (Doktora tezi). Yök tez veri tabanından erişildi (Tez no: 239242).

Say, A. (2010). Müzik ansiklopedisi. Ankara: Müzik Ansiklopedisi Yayınları.

Selanik, C. (1996). Müzik sanatının tarihsel serüveni. Ankara: Doruk Yayıncılık.

Şen, S. S. (1992). Evrensel keman teknikleri kullanılarak Türk folkloruna ve evrensel müziğe dayalı özgün keman etütlerinin yaratılması. (Yüksek lisans tezi). Yök tez veri tabanından erişildi (Tez no: 367090).

Uçan, A. ve Günay, E. (1974). Mektupla Yükseköğretim Keman 1633-6. Ankara: Mektupla Öğretim Merkezi. 